UDC 624.014

\title{
FINITE-ELEMENT SIMULATION OF PDC DRILL BIT'S OPERATIONAL STRESS-STRAIN STATE
}

\author{
Tetiana Pryhorovska; Olexandr Pryhorovskyi
}

\author{
Ivano-Frankivsk National Technical University of Oil and Gas, \\ Ivano-Frankivks, Ukraine
}

\begin{abstract}
Summary. The article presents finite-element simulation results of the PDC drill bit's operational stressstrain state in order to determine the most stressed and deformed areas in drill bit's operation. Operational stressstrain state of drill bit definition is important because external diameter of the drill bit is the main operation parameter; and drill bit external diameter decreasing is a cause of drill bit failure. There were simulated operations of PDC drill bit with welded blades and a solid drill bit. The authors used the Ansys Workbench (academic license version) to specify the biggest deformation areas. They are the welding joint areas and thread area. The authors considered the dependence of stresses and strains in these areas on the thickness of a welding joint. We can conclude that bits with welded blades are more prone to external diameter deformation; they have worse performance. This fact stipulates requirements for technology improvement of manufacturing these types of bits.
\end{abstract}

Key words: PDC drill bit, finite element method, modeling, stress-strain state, thread, welding joint.

https://doi.org/10.33108/visnyk_tntu2020.01.045

Received 05.03.2020

Statement of the problem. A modern drilling tool operates under high loads in a corrosive environment. Therefore, the challenge is to improve its manufacturing technology, that is, the structure elements containing stress concentrators (welding joints of welded bit bodies, threads etc.) are under the study. Modern drill bits are made either solid (sintered alloy sintering) or the blades are welded to the steel body. In this case, domestic manufacturers mainly produce bits with blades welded to the body (Figure 1).
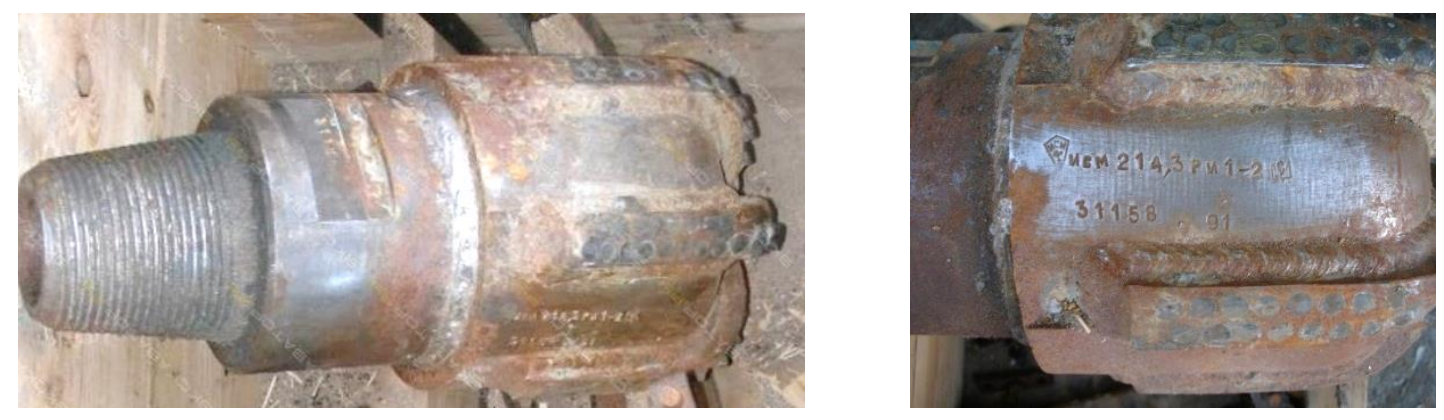

Figure 1. ISM drill bits with welded blades (photos from the Internet)

According to the foreign standards, the outer diameter is the main dimension that determines the operational suitability of a bit of any type and design. In fact, the loss of the bit diameter is one of the reasons for the bit failure and the cessation of drilling [1]. Before drilling, the bit diameter is measured by means of a special calibration ring (Figure 2). The tolerances 
of the outer diameter of the PDC type drill bits according to API are presented in Table 1 [2].

Table 1

Tolerances of the outer diameter of drill bits

\begin{tabular}{|l|c|c|}
\hline \multicolumn{1}{|c|}{ Nominal outer diameter of a bit, $\mathrm{mm}$} & In inches & In millimetres \\
\hline From 85,76 to $349,2 \mathrm{~mm}$ (inclusively) & $-0 \ldots+0,313(1 / 32)$ & $-0 \ldots+0,794$ \\
\hline From 355,6 to 444,5 mm (inclusively) & $-0 \ldots+0,625(1 / 16)$ & $-0 \ldots+1,588$ \\
\hline From 447,88 and more & $-0 \ldots \ldots+0,938(3 / 32)$ & $-0 \ldots+2,381$ \\
\hline
\end{tabular}
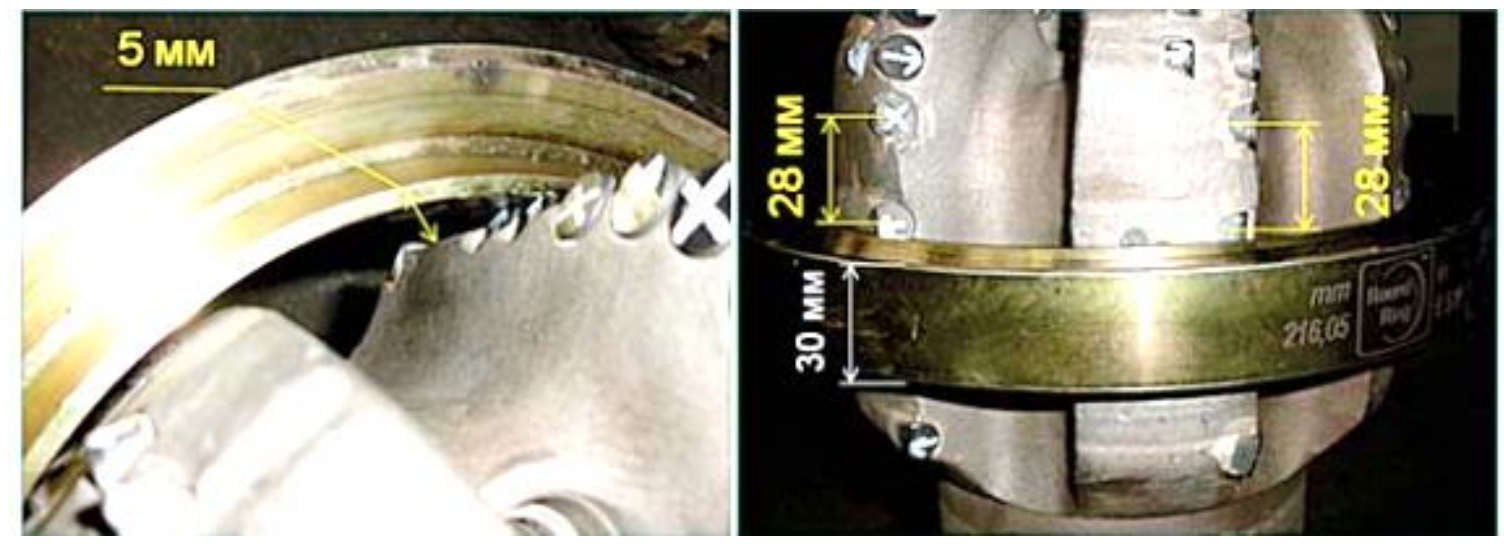

Figure 2. Control by 216,05 Round Ring ${ }^{\mathrm{TM}}$ gauge (nominal external diameter of the drill bit is $215,99 \mathrm{~mm}\left(8 \frac{1}{2}{ }^{*}\right)$, Round Ring ${ }^{\mathrm{TM}}$ gauge's height $\left.-30 \mathrm{~mm}\right)$

Analyses of available investigations. The information on the stress-strain state of the tool is insufficient, therefore, the performance of the bit elements could not be substantiated, and the problems of optimizing the bit design could not be solved [3].

The issues of simulating the stress-strain state of cutting tools in operation are covered in the works of scientists O. G. Blinkov [4], V. V. Solonychnyi, V. M. Vakaliuk, Y. M. Liakh, D. Yu. Zhuravlev [5]. Based on the finite element method, the drilling tool operation was studied in the works of S. Dinescu, I. Kertész (Brînaş), M. Vesa (Benea) [6], Mahdi Saadati [7], P. V. Burkov [8], Guangjian Dong and Ping Chen [9], Yi Zhou, Lin Wang [10], J. Pei, Z. Yinghu, W. Zhenquan, S. Dongyu [11], V. Srinivas [12], Ju P., Wang Z., Zhai Y., Su D., Zhang Y. \& Cao Z. [13], Hlembotska L., Balytska N., Melnychuk P., Melnyk O. [19], Kovalchuk Ya., Shynhera N., Chornomaz N. [20].

Thus, in [5], the stress-strain state of a PDC-type solid bit in its operation was analysed. The central cutters and blades of the bit were found to be the most loaded ones. The same conclusion was made in [12], namely, the load on the cutter was inversely proportional to the centre of the bit. In [16], the most loaded sections were found to be the sections of the cutters, the area of the «body-blade» in the central part of the bit, and the bit rifle.

The contact forces that occur during drilling and distort the wellbore were studied in [13]. The vibrations of the bit and the column during drilling were studied in [14]. In [16], it was considered how vibration could be used to improve rock fracture efficiency. In [15], experimental and finite element characteristics of rock fracture were compared to refine the rock model. 
Therefore, we can summarize that the vast majority of works focuses on the problem of rock destruction; it is aimed at the study of stress-strain state of rocks, and rarely at the determining of the shape and size of structural elements.

Objective of the paper. The objective of this paper is to simulate the cut-erase type bits' operation in order to determine the stresses and strains in places of stress concentration. Based on the simulation analysis, the necessary recommendations on the improvement of bit production technology should be made.

Statement of the task. To determine the most loaded sections of the drill bit in its operation, a finite element model of the bit was developed; the model of the drilling head ISM 14.4764.1001 (Figure 3) was adopted as an analogue.

Since cutting is a rather complicated process, its complete analytical description is now virtually impossible. Therefore, a numerical experiment was conducted using a number of assumptions:

1. Heat production in the cutting area was not taken into account.

2. The coefficient of friction on the front surface was assumed constant over its entire length, regardless of the stresses involved.

3. The coefficient of friction on the back surface was assumed constant and equal to the coefficient on the front surface.

4. The cutting edge was assumed constant, the shape of the cutter was not changed. The wear of the cutter during processing was not taken into account.

Both solid and welded bodies were considered.

The model accepted the following limitations:

- Ambient temperature $200^{\circ} \mathrm{C}$.

- The bit could rotate and move about the vertical axis; the rock was assumed fixed.

- The movement speed of the bit along the vertical axis was set $0,1 \mathrm{~m} / \mathrm{s}$.

- The rotation speed of the bit $1 \mathrm{rad} / \mathrm{s}$.

- The pressure 10,000 Pa on the attachment surface of the bit was set.

The stress-strain state of the bit and rock elements was determined in simulation.
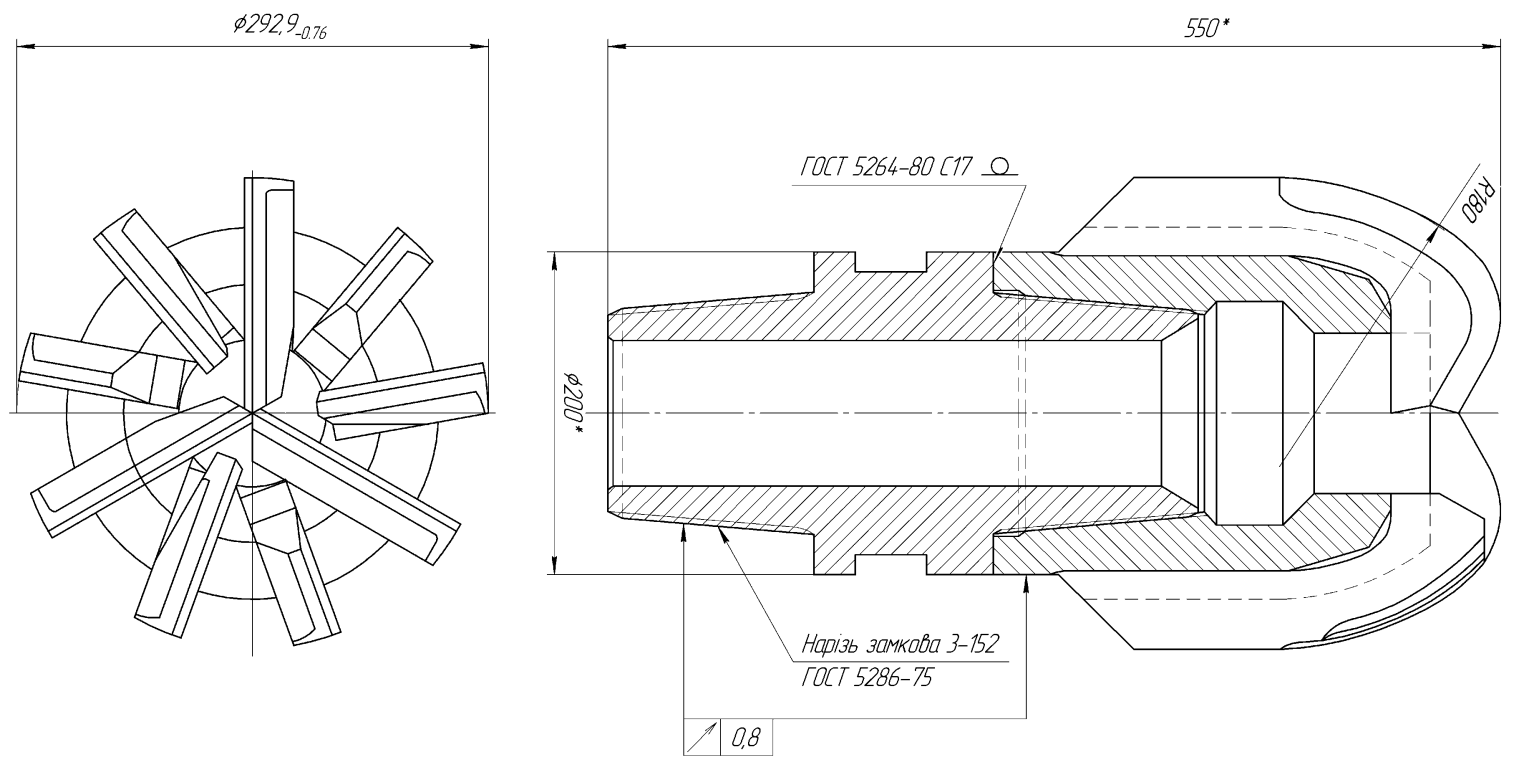

Figure 3. ISM 14.4764.1001 drill bit (assembly drawing) 
Materials used for simulation are presented in Table 1 . The thickness of the welding joint is $10 \mathrm{~mm}$.

\section{Table 2}

Bit and rock elements used in simulation

\begin{tabular}{|l|c|c|c|c|}
\hline \multicolumn{1}{|c|}{ Element/Material } & Rock & Blade & Welding joint & Bit body \\
\hline $\begin{array}{l}\text { Body with the } \\
\text { welded blades }\end{array}$ & Concrete-L & BoronCarbi & $\begin{array}{c}\text { Constructional } \\
\text { Steel }\end{array}$ & $\begin{array}{c}\text { Constructional } \\
\text { Steel }\end{array}$ \\
\hline Solid body & Concrete-L & BoronCarbi & - & BoronCarbid \\
\hline
\end{tabular}

Table 3

Materials parameters used in simulation

\begin{tabular}{|l|c|c|c|}
\hline \multicolumn{1}{|c|}{ Material/characteristics } & Density & $\begin{array}{c}\text { Volumetric modulus of } \\
\text { elasticity }\end{array}$ & Shear module \\
\hline Concrete-L & $2440 \mathrm{~kg} / \mathrm{m}^{3}$ & $0,42 \cdot 10^{5} \mathrm{~Pa}$ & $7,88 \cdot 10^{9} \mathrm{~Pa}$ \\
\hline BoronCarbi & $2516 \mathrm{~kg} / \mathrm{m}^{3}$ & $2,33 \cdot 10^{11} \mathrm{~Pa}$ & $1,99 \cdot 10^{11} \mathrm{~Pa}$ \\
\hline Constructional Steel & $7900 \mathrm{~kg} / \mathrm{m}^{3}$ & $2 \cdot 10^{11} \mathrm{~Pa}$ & $7,9 \cdot 10^{9} \mathrm{~Pa}$ \\
\hline
\end{tabular}

Mathematical model of investigation. The model was based on the fundamental equation of motion of solid body points, which can be deduced [17]:

$$
\rho \ddot{u}_{i}=\rho f_{i}+\sigma_{i j, j}
$$

if $u, \dot{u}, \ddot{u}$ - respectively, the vectors of the moving points of the solid body, their velocity and acceleration; $f_{i}$ - density at the moment of acceleration; $\rho$-density at a given time; $\sigma_{i j}-$ components of the Cauchy stress tensor.

Boundary conditions are mathematically formulated:

in the forces at the boundaries of the body

$$
\sigma_{i j, j} \cdot n_{i}=F(t)
$$

in movements at the boundary of the body

$$
u=U
$$

in the forces at the contact boundary

$$
\left(\sigma^{+}-\sigma^{-}\right) n=0 \text { if } u^{+}=u^{-} .
$$

Mass conservation equation

$$
\rho V=\rho_{0}
$$

if $V=\operatorname{det}\left(\frac{\partial u_{i}}{\partial U_{j}}\right)-$ the initial density of the material. 
Energy equation

$$
\dot{E}=V \cdot s_{i j} \cdot \dot{\varepsilon}_{i j}-(\rho-q) \dot{V}
$$

if $s_{i j}=\sigma_{i j}+(p+q) \delta_{i j}-$ components of the Cauchy stress tensor deviator; $p=-\frac{1}{3} \sigma_{i j} \delta_{i j}-q$ hydrostatic pressure (negative when stretched); $q$ - bulk viscosity; $\delta_{i j}$ - Kronecker symbol; $\dot{\varepsilon}_{i j}$ - components of the strain rate tensor.

The assumption concerning the flat deformation is accepted in the work, which is well confirmed by the experiment. $\mathrm{u}_{\mathrm{z}}=0, \varepsilon_{\mathrm{z}}=0, \mathrm{~b}=1$

The forces acting on a solid body can be determined by the formula [17]

$$
f=f_{\text {load }}+f_{\text {contact }}-l
$$

$f_{\text {load }}$ - the volume and external forces acting on the body are reduced to the CE grid nodes; $f_{\text {contact }}-$ the forces at the contact boundary of the body are reduced to the CE grid nodes; $l$ internal forces.

Based on these fundamental equations, the numerical calculation of the displacements of solid's nodes can be performed applying the following iterative procedure.

Assumedly, at the initial time, in all points of the simulated body

$$
\ddot{u}_{i}=0, \dot{u}_{i}=0, u_{i}=0 ; f_{\text {load }_{i}}=0, f_{\text {contact }_{i}}=0, l_{i}=0 \text {. }
$$

Let us find the moving points of the body in some infinitely short time $\Delta t$. To do this, the kinematic boundary conditions and loads determined by the conditions of the problem at the given point of time should be set:

$$
\ddot{u}_{i}=\ddot{U}_{i}, \dot{u}_{i}=\dot{U}_{i}, u_{i}=U_{i} ; f_{\text {load }_{i}}=F_{\text {load }_{i}} \text {. }
$$

Based on the equation (1), the vector of accelerations is calculated:

$$
\left.\ddot{u}_{i}\right|_{t}=\left.\left(M_{i j}^{-1}\right)\left(f_{\text {load }_{i}}+f_{\text {contact }_{i}}-l_{i}\right)\right|_{t}
$$

$\mathrm{M}$ - the matrix of masses.

Next, by integrating with the central difference method, the velocity vector is calculated:

$$
\left.\dot{u}_{i}\right|_{t+\frac{\Delta t}{2}}=\left.\dot{u}_{i}\right|_{t-\frac{\Delta t}{2}}+\left.\Delta t \ddot{u}_{i}\right|_{t} .
$$

Similarly, the vector of displacements of body points is calculated:

$$
\left.u\right|_{t}=\left.u\right|_{t}+\left.\Delta t \dot{u}\right|_{t+\frac{\Delta t}{2}}
$$

Evidently, displacements of body points will cause a force reaction of the body in the form of internal forces $I$, which remain unknown. To determine them, the strain rate tensor should be deduced: 


$$
\left.\dot{\varepsilon}_{i j}\right|_{t+\frac{\Delta t}{2}}=\left.\frac{1}{2}\left(\frac{d \dot{u}_{i}}{d x_{j}}+\frac{d \dot{u}_{j}}{d x_{i}}\right)\right|_{t+\frac{\Delta t}{2}}
$$

The decomposition is performed:

$$
\dot{\varepsilon}_{i j}=\dot{\varepsilon}_{i j}^{e}+\dot{\varepsilon}_{i j}^{p},
$$

if $\dot{\varepsilon}_{i j}^{e}$ - elastic strain rate tensor; $\dot{\varepsilon}_{i j}^{p}$ - plastic strain rate tensor.

Then, the increment of any component of deformation

$$
\left.d \varepsilon_{i j}\right|_{t+\Delta t}=\left.\Delta t \dot{\varepsilon}_{i j}^{e}\right|_{t+\frac{\Delta t}{2}} .
$$

The magnitude of any component of deformation:

$$
\left.\varepsilon_{i j}\right|_{t+\Delta t}=\left.\varepsilon_{i j}\right|_{t}+\left.d \varepsilon_{i j}\right|_{t+\Delta t} .
$$

Considering the high deformation rates in the chip formation zone at practically applied cutting speeds [17], the assumption about the adiabatic nature of the deformation is accepted. Then, the temperature resulting from such deformation can be calculated

$$
T=\eta \frac{\sigma_{i j} \dot{\varepsilon}_{i j}^{p l}}{\rho C_{V}} .
$$

Applying the rheological model (equation of state) of the deformable body material, the stress at the nodes of the CE is deduced [3]:

$$
\left.\sigma_{i j}\right|_{t+\Delta t}=F\left(\left.\sigma_{i j}\right|_{t},\left.\varepsilon_{i j}\right|_{t+\Delta t},\left.\dot{\varepsilon}_{i j}\right|_{t+\Delta t}, T\right)
$$

The internal forces at the nodes are assembled

$$
l_{i}=l\left(\sigma_{i j}\right) .
$$

The rheological model of elastic deformations is presented in this paper by the generalized Hooke law. This rheological model is used to calculate stresses both in the tool and in the workpiece. The workpiece is also deformed plastically. The Johnson - Cook equation describes, for this case, the experiment in the best way:

$$
\sigma_{s}=\left(A+B\left(\bar{\varepsilon}^{p}\right)^{n}\right)\left(1+C \ln \left(\dot{\bar{\varepsilon}}^{p^{*}}\right)\right)\left(1-\left(T^{*}\right)^{m}\right),
$$

if $\bar{\varepsilon}^{p}$ - intensity of plastic deformation; $\dot{\bar{\varepsilon}}^{p^{*}}=\dot{\bar{\varepsilon}}^{p} / \dot{\bar{\varepsilon}}_{0} p^{*}-$ intensity of plastic deformation rate; $T^{*}=\left(T-T_{0}\right) /\left(T_{i \ddot{\varepsilon}}-T_{0}\right)-$ homologous temperature.

Then, the forces at the contact boundaries should be determined. The solution of the contact problem and the determination of forces at the contact boundary $f_{\text {contact }_{i}}$ are performed by the method of penalties. The contact tangential stresses were calculated by the model $\tau=\min \left(\mu \sigma_{n}, \tau_{\max }\right)$, if $\mu$ is the coefficient of friction; $\tau_{\max }-$ maximum contact stresses; $\sigma_{n}-$ normal stresses on the contact pad. 
Further, the performance of the destruction criterion in each CE workpiece is verified. In this paper, the criterion for the plastic material destruction is the criterion of accumulated plastic deformation in the form of Johnson-Cook:

$$
D=\sum \frac{\Delta \bar{\varepsilon}}{\bar{\varepsilon}_{f}} \geq 1
$$

if $\bar{\varepsilon}_{f}=\left(D_{1}+D_{2} \exp \left(D_{3} \sigma^{*}\right)\right)\left(1+D_{4} \ln \dot{\varepsilon}^{*}\right)\left(1+D_{5} T^{*}\right)-$ limit value of accumulated plastic deformations, $\sigma^{*}=\sigma / \sigma_{\text {екв }} \sigma^{*}=\sigma / \sigma_{\text {уе } \hat{a} a}-$ eq - equivalent - hydrostatic pressure; $\sigma_{э к в}-$ Von Mises stress. In those CEs, where the condition $D=\sum \frac{\Delta \bar{\varepsilon}}{\bar{\varepsilon}_{f}} \geq 1$ is satisfied, the Cauchy stress tensor is set to 0 , and the grids are deleted in CE.

The calculations are repeated. The current time $\mathrm{t}$ is then increased by the integration step. The maximum integration step is determined by the formula $\Delta t_{\max }=\min (L / c)$, where $c=\sqrt{\frac{E}{\rho\left(1-v^{2}\right)}}$ is the velocity of a plane sound wave in the material; the characteristic dimension of the CE.

Simulation results. Thus, a feature of this approach is the dynamic statement of the problem. This made it possible to obtain qualitative characteristics of the process for the entire life of the cutter. In this work, the practical implementation of the model was carried out using linear triangular finite elements [18]. When explicitly sampled over time, these CEs provide good convergence and high computation speeds. The simulation results are presented in Figures 4-11. The simulation lasted for $12,4 \mathrm{~s}$, the model had 41280 nodes and 8480 elements, and grid compression was not expected due to hardware limitations (including insufficient PC power).

In this case, the grid compression would not significantly affect the result, since the aim of the study was, primarily, to obtain a qualitative picture of stresses distribution and to determine the places of stress concentration in order to make recommendations for improving the bit production technology.

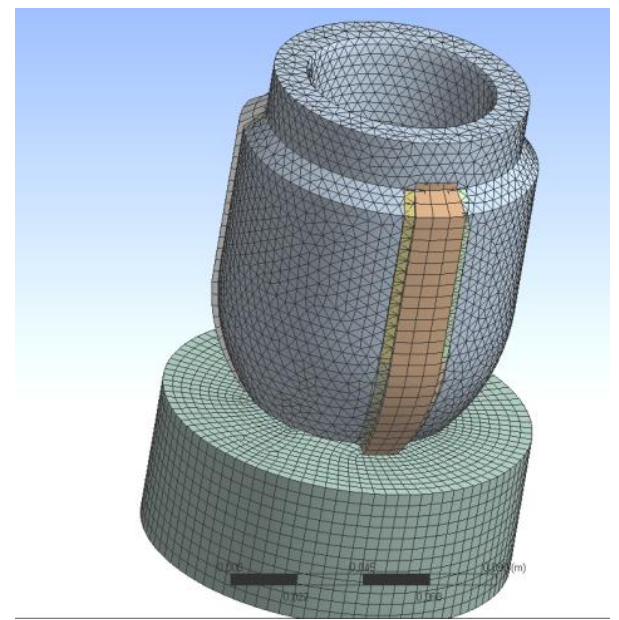

Figure 4. Ansys WorkBench 18,2 screenshot (academician version) with a grid set on the drill bit model with welded blades

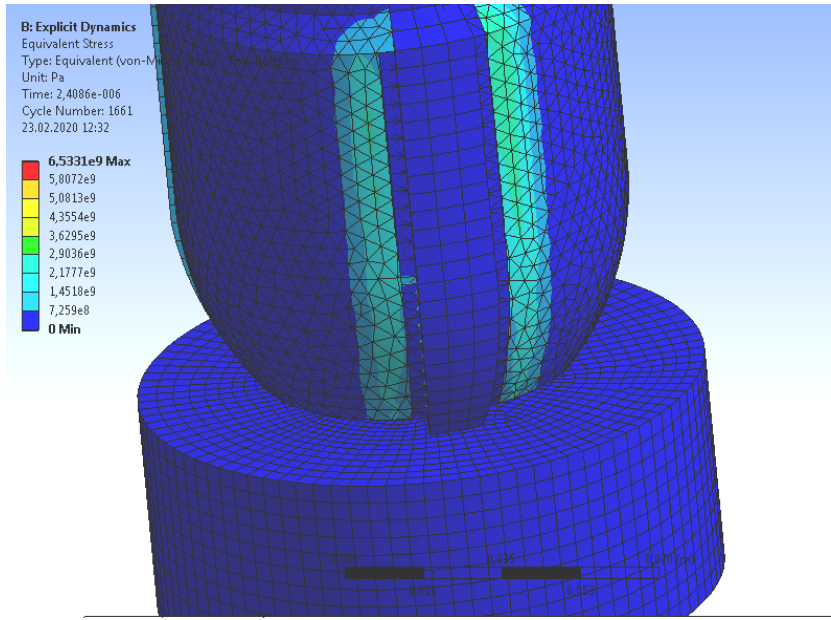

Figure 5. Stresses distribution in the drill bit elements with welded blades (Ansys WorkBench 18,2 screenshot (academician version)) 


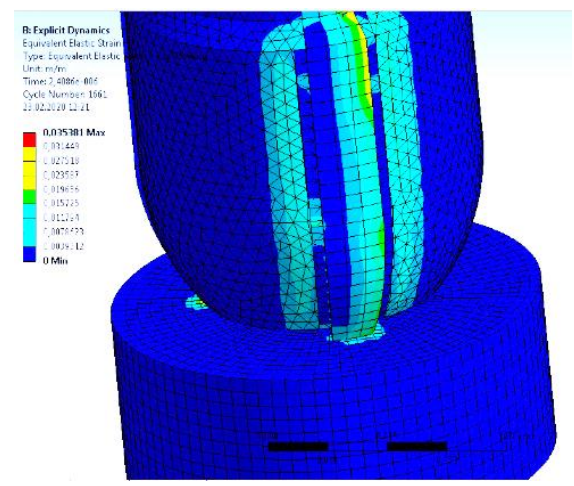

Figure 6. Deformation distribution in the drill bit elements with welded blades while digging in (Ansys WorkBench 18,2 screenshot (academician version))

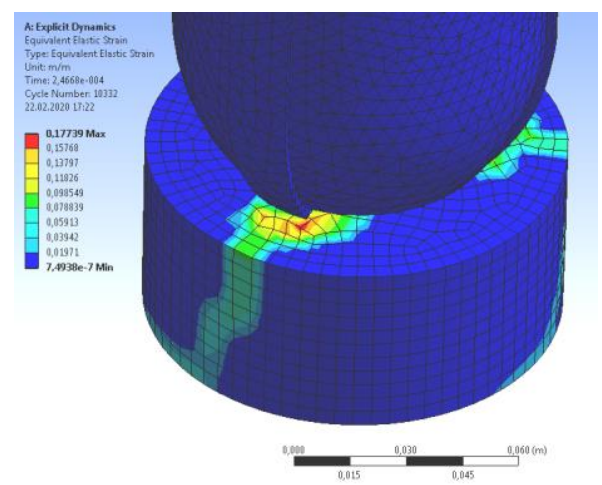

Figure 8. Stresses distribution in the solid drill bit while digging in (Ansys WorkBench 18,2 screenshot (academician version))

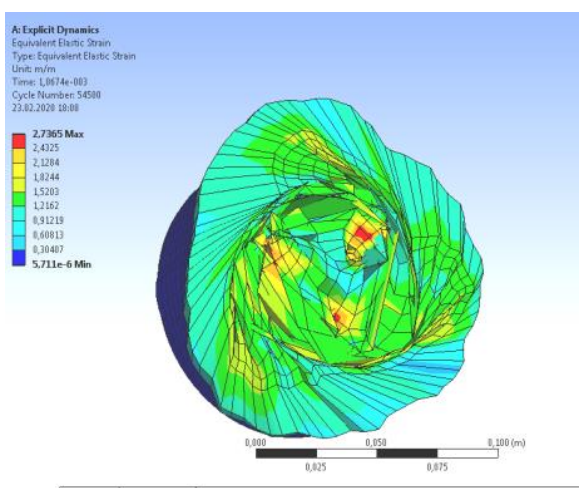

Figure 10. Formation of a whole during rock destruction by the solid drill bit (Ansys

WorkBench 18,2 screenshot (academician version))

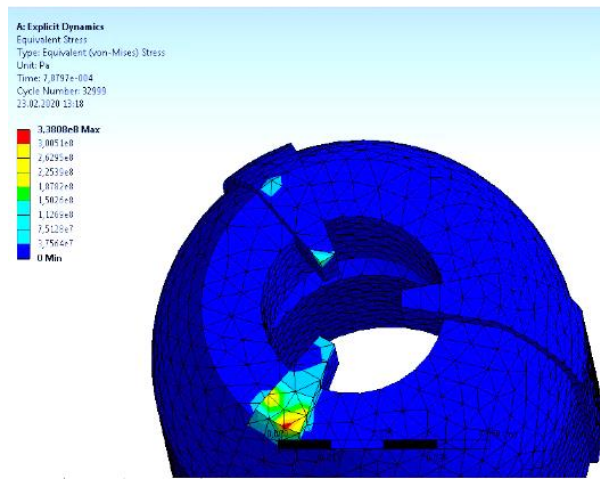

Figure 7. Stresses distribution in the solid drill bit while digging in (Ansys WorkBench 18,2 screenshot (academician version))

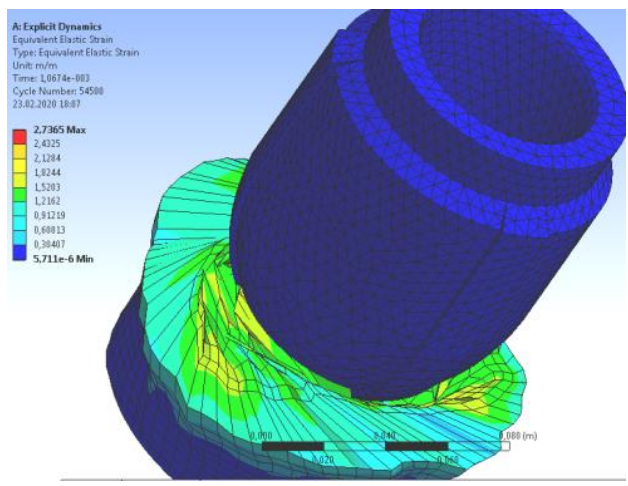

Figure 9. Deformation distribution in the solid drill bit during rock destruction (Ansys WorkBench 18,2 screenshot (academician version))

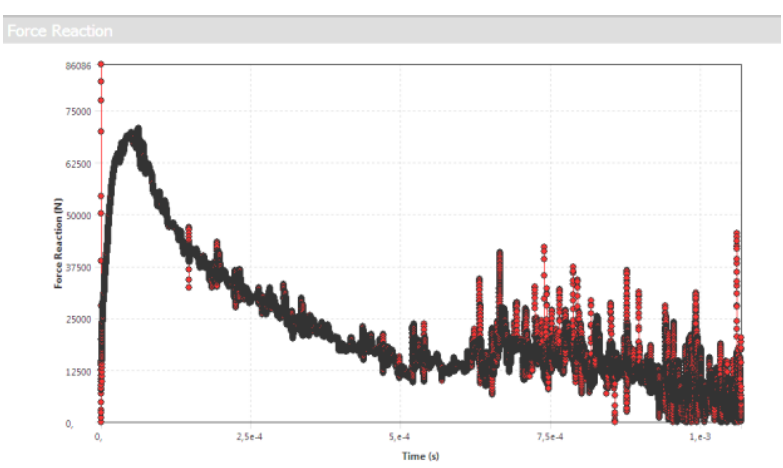

Figure 11. Rock reation force dynamics during rock destruction by the solid drill bit (Ansys

WorkBench 18,2 screenshot (academician version))

According to the simulation results, the greatest stresses in solid bits and bits with welded blades occur in time of their digging in.

In all types of bits, the highest stresses occur in the threaded sections. In the bits with welded blades, the highest stresses occur in the areas of welding joints. 
Table 4

Comparison of stresses and strains that occur in the bit elements during the study

\begin{tabular}{|l|c|c|}
\hline \multicolumn{1}{|c|}{ Parameter/Bit element } & Solid body & $\begin{array}{c}\text { Body with welded } \\
\text { blades }\end{array}$ \\
\hline Maximum stress Pa (in a bit element) & $3,80810^{9}$ & $6,5310^{8}$ \\
\hline Maximum deformations (in bit element), $\mathrm{m} / \mathrm{m}$ & 0,0358 & 0,027 \\
\hline Sections with maximum stresses & Thread & Welding joint \\
\hline Maximum stresses in welding joints, Pa & - & $3,910^{8}$ \\
\hline Mean stresses in welding joints, Pa & - & $3,3510^{8}$ \\
\hline Maximum stresses in a threaded section, Pa & $3,0510^{8}$ & $3,210^{8}$ \\
\hline Mean stresses in a threaded section, $\mathrm{Pa}$ & $3,110^{8}$ & $2,910^{8}$ \\
\hline Maximum deformations in welding joints, $\mathrm{m} / \mathrm{m}$ & - & 0,027 \\
\hline Maximum deformations in a threaded section, $\mathrm{m} / \mathrm{m}$ & 0,021 & 0,023 \\
\hline
\end{tabular}

Thus, the solid bits are characterized by lower stresses and strains. The maximum stress level in the bits with welded blades was 1,5 higher than in the solid bits. The mean stresses in the threaded section are slightly higher in the bits with welded blades $\left(3,210^{8} \mathrm{~Pa}\right.$ in the bits with welded blades and 3,05 $10^{8} \mathrm{~Pa}$ in the bits with solid body).

The highest magnitude of stresses occur near the welding joint, which can lead to defects during loading. Maximum stresses 3,9 $10^{8} \mathrm{~Pa}$ and mean stresses 3,35 $10^{8} \mathrm{~Pa}$ are observed in the area of welding joints of the bits with welded blades.

At the same time, the magnitude of deformations in the threaded areas and welding joints (in bits with welded blades) is of particular interest. Such scientific interest is explained by the fact that deformations in the threaded area can cause the so-called vortex movement of a bit that occurs during drilling [5]. For example, deformations in the threaded area of a solid body are $0,021 \mathrm{~m} / \mathrm{m}$, and deformations in the threaded area of the bits with welded blades $0,023 \mathrm{~m} / \mathrm{m}$. Deformation in the area of welding joints of the bits with welded blades is 0,027 $\mathrm{m} / \mathrm{m}$.

Deformations occurring in the area of welding joints cause the loss of the bit diameter, which is the main operational indicator of the bit operation. Thus, we can conclude that bits with welded blades are more prone to loss of diameter, that is, possess worse performance indicators.

This fact raises the question of the dependence of the stresses and strains on the thickness of a welding joint. The technology of ISM-type bits production implies the large sizes of welding joints, which ensures reliable and durable mounting and, at the same time, causes significant bit deformation during welding. The next stage of the study was to determine the feasibility of reducing the thickness of a welding joint. In our work, welding joints of 5,7 , and $10 \mathrm{~mm}$ thickness were considered for simulation. The results of the finite element study are presented in Table 5.

Table 5

Determination of mean stresses and deformations of a welding joint of different thickness (according the results of finite element simulation)

\begin{tabular}{|c|c|c|}
\hline Welding joint thickness & Stress, Pa & Deformation magnitude, $\mathrm{m} / \mathrm{m}$ \\
\hline $5 \mathrm{~mm}$ & $2,7510^{8}$ & 0,012 \\
\hline $7 \mathrm{~mm}$ & $3,0510^{8}$ & 0,019 \\
\hline $10 \mathrm{~mm}$ & $3,3510^{8}$ & 0,023 \\
\hline
\end{tabular}


The level of stresses and deformations that occur in operation depends on the thickness of a welding joint: the reduction of the welding joint thickness causes a decrease in stresses and deformations. In this regard, the thickness of the welding joint is proposed to be reduced.

Conclusions. The article investigates the stress-strain state of solid bits and bits with welded blades under operational conditions in order to improve the technology of bit body production. For this purpose, to determine the forces acting on the bit, the process of rock destruction by the bit was analytically studied. Based on the data obtained to determine the areas of maximum stresses, a finite element study of the bit body (solid and with welded blades) was conducted. According to the finite element study, the maximum stresses in both solid bits and bits with welded blades occur in time of their digging in. In all types of bits, the sections with the maximum stresses are the threaded sections. In bits with welded blades, the maximum stresses occur in the areas of welding joints. Solid bits are characterized by lower stresses and strains. The maximum stress level in the bits with welded blades was 1,5 higher than in the bits with solid body. The mean stresses in the threaded section are slightly higher in the bits with welded blades $\left(3,210^{8} \mathrm{~Pa}\right.$ in the bits with welded blades and 3,05 $10^{8} \mathrm{~Pa}$ in the bits with solid body). The highest magnitude of stresses occurs near the welding joint, which can lead to defects in loading. In the area of welding joints of bits with welded blades, maximum stresses are 3,9 $10^{8} \mathrm{~Pa}$, and mean stresses $-3,3510^{8} \mathrm{~Pa}$. Deformations occurring in the area of welding joints cause the loss of the bit diameter, which is the main operational parameter of the bit performance. Thus, we can conclude that bits with welded blades are more prone to loss of diameter, that is, possess worse operational parameters. The reduction of thickness of the welding joint was proposed. The finite element study of the operation of bits with welding joints of 5, 7 and $10 \mathrm{~mm}$ was conducted. The level of stresses and strains that occur in operation depends on the thickness of the welding joint: the reduction of thickness of the welding joint causes a decrease in stresses and strains. In this regard, the thickness of the welding joint is proposed to be reduced.

\section{References}

1. Diamond bit wear codes: website. URL: http://vbs-service.ru (date of access: 03.04.2020).

2. Khorunov V. B, Stefaniv B. V., Sabadash O. M., Voronov V. V. Features of wear and maintainability criteria for drill bits with diamond carbide cutters. Automatic welding. 2012. No. 10. P. 43-47. [In Russian].

3. Blinkov O. G. Possibilities of physical modeling of the stress-strain state of the supporting elements of a conical bit. UGSU News. 2017. 1 (45). P. 65-67. [In Russian]. https://doi.org/10.21440/2307-2091-2017$1-65-67$

4. Solonychnyi V. V., Vakaliuk V. M., Liakh Y. M., Zhuravlev D. Yu. Stress-strain state of composite materials. Scientific Bulletin of the Ivano-Frankivsk National Technical University of Oil and Gas. 2011. № 2. P. 28-30.

5. Dinescu S., Kertész (Brînaş) I., Vesa (Benea) M. Study on the stress and strain of the drill bits using the finite element method. MultiScience - XXXII. MicroCAD: International Multidisciplinary Scientific Conference University of Miskolc (5-6 September, 2018.). 2008. https://doi.org/10.26649/musci.2018.029

6. Saadati M., Forquin P., Weddfelt K., Larsson P.-L., Hild F. Granite rock fragmentation at percussive drilling - experimental and numerical investigation. International Journal for Numerical and Analytical Methods in Geomechanics. 2014. 38 (8). P. 828-843. https://doi.org/10.1002/nag.2235

7. Burkov P. V. et al. Computer Simulation of Strain at Drilling with PDC Bits. Applied Mechanics and Materials. 2015. Vol. 770. P. 461-463. https://doi.org/10.4028/www.scientific.net/AMM.770.461

8. Guangjian D., Ping C. 3D Numerical Simulation and Experiment Validation of Dynamic Damage Characteristics of Anisotropic Shale for Percussive-Rotary Drilling with a Full-Scale PDC Bit. Energies. 2018. № 11. P. 13-26. https://doi.org/10.3390/en11061326

9. Zhou Y., Wang L. Study on Optimum Structural Design of Roller Bit Bearing Double Rubber Ring Seal. International Journal of Science and Research (IJSR). 2016. Volume 5. Issue 6. P. 48-58. https://doi.org/10.21275/v5i6.NOV164119

10. Pei J., Yinghu Z., Zhenquan W., Dongyu S. Numerical simulation of polycrystalline diamond compact bit rock-breaking process based on smooth partcle hydrodynamic-finite element coupling method. Proceedings. 2013. № 2 . 
11. Srinivas V. Design and Analysis of Drill Bit with Various Materials Using ANSYS. Journal of Engineering and Applied Sciences. 2018. № 13. P. 5218-5221.

12. Ju P., Wang Z., Zhai Y., Su D., Zhang Y. \& Cao Z. Numerical simulation study on the optimization design of the crown shape of PDC drill bit. Journal of petroleum exploration and production technology. 2014. № 4. P. 343-350. https://doi.org/10.1007/s13202-013-0091-9

13. Callejo A., Arbatani S., Kövecses J., Kalantari M., Marchand N. Drill Bit Contact Dynamics Including Side Cutting: Simulation and Validation. Journal of Energy Resources Technology. 2017. № 139. P. 184197. https://doi.org/10.1115/1.4035514

14. Shi J., Wang J., Liu X. The Nonlinear Dynamics Simulation of Drill String-drill Bit-rock Based on ABAQUS: 2nd International Conference on Civil, Materials and Environmental Sciences (April, 2015.) 2015. https://doi.org/10.2991/cmes-15.2015.125

15. Fourmeau M, Kane A, Hokka M. Experimental and numerical study of drill bit drop tests on Kuru granite. Phil. Trans. R. Soc. 2016. № 375. https://doi.org/10.1098/rsta.2016.0176

16. Hrydzhuk Y. S. Research of axial force and the torque action on a drill string at rotary and combined drilling methods. Scientific Bulletin of Ivano-Frankivsk National Technical University of Oil and Gas. 2018. № 2 (45). P. 7-15. https://doi.org/10.31471/1993-9965-2019-2(45)-7-15

17. Zhang W., Dang W., Chen W., Zhang Y. Individual Drilling Bit Design and Optimization in Mahu Area. MATEC Web of Conferences, 2017. 128. https://doi.org/10.1051/matecconf/201712805017

18. Zaloga V. A., Krivoruchko D. V., Khvostik S. N. Imitation model of rectangular free cutting. Bulletin of Sumy State University. 2005. № 11. C. 55-66. [In Russian].

19. Hlembotska L., Balytska N., Melnychuk P., Melnyk O. Computer modelling power load of face mills with cylindrical rake face of inserts in machining difficult-to-cut materials. Scientific Journal of TNTU. 2019. Vol. 93. No. 1. P. 70-80. https://doi.org/10.33108/visnyk_tntu2019.01.070

20. Kovalchuk Ya., Shynhera N., Chornomaz N. Stress-strain state of a bottom chord of a welded roof truss. Scientific Journal of TNTU. 2019. Vol.93. No. 1. P. 41-46. https://doi.org/10.33108/ visnyk_tntu2019.01.041

\section{Список використаної літератури}

1. Коды износа алмазных долот. URL: http://vbs-service.ru (дата звернення: 04.03.2020).

2. Хорунов В. Б., Стефанив Б. В., Сабадаш О. М., Воронов В. В. Особенности износа и критерии ремонтопригодности буровых долот с алмазно-твердосплавными резцами. Автоматическая сварка. 2012. № 10. С. 43-47.

3. Блинков О.Г. и др. Возможности физического моделирования напряженно-деформированного состояния опорных элементов шарошечного долота. Известия УГГУ. 2017. Вып. 1 (45). С. $65-67$. https://doi.org/10.21440/2307-2091-2017-1-65-67

4. Солоничний В. В., Вакалюк В. М., Лях Ю. М., Журавльов Д. Ю. Напружено-деформований стан композиційних матеріалів. Науковий вісник Івано-Франківського національного технічного університету нафти і газу. 2011. № 2. С. 28-30.

5. Dinescu S., Kertész (Brînaş) I., Vesa (Benea) M. Study on the stress and strain of the drill bits using the finite element method. MultiScience - XXXII. MicroCAD: International Multidisciplinary Scientific Conference University of Miskolc (5-6 September, 2018.). 2008. https://doi.org/10.26649/musci.2018.029

6. Saadati M., Forquin P., Weddfelt K., Larsson P.-L., Hild F. Granite rock fragmentation at percussive drilling - experimental and numerical investigation. International Journal for Numerical and Analytical Methods in Geomechanics. 2014. 38 (8). P. 828-843. https://doi.org/10.1002/nag.2235

7. Burkov P. V. et al. Computer Simulation of Strain at Drilling with PDC Bits. Applied Mechanics and Materials. 2015. Vol. 770. P. 461-463. https://doi.org/10.4028/www.scientific.net/AMM.770.461

8. Guangjian D., Ping C. 3D Numerical Simulation and Experiment Validation of Dynamic Damage Characteristics of Anisotropic Shale for Percussive-Rotary Drilling with a Full-Scale PDC Bit. Energies. 2018. № 11. P. 13-26. https://doi.org/10.3390/en11061326

9. Zhou Y., Wang L. Study on Optimum Structural Design of Roller Bit Bearing Double Rubber Ring Seal. International Journal of Science and Research (IJSR). 2016. Volume 5. Issue 6. P. 48-58. https://doi.org/10.21275/v5i6.NOV164119

10. Pei J., Yinghu Z., Zhenquan W., Dongyu S. Numerical simulation of polycrystalline diamond compact bit rock-breaking process based on smooth partcle hydrodynamic-finite element coupling method. Proceedings. 2013. № 2 .

11. Srinivas V. Design and Analysis of Drill Bit with Various Materials Using ANSYS. Journal of Engineering and Applied Sciences. 2018. № 13. P. 5218-5221.

12. Ju P., Wang Z., Zhai Y., Su D., Zhang Y. \& Cao Z. Numerical simulation study on the optimization design of the crown shape of PDC drill bit. Journal of petroleum exploration and production technology. 2014. № 4. P. 343-350. https://doi.org/10.1007/s13202-013-0091-9 
13. Callejo A., Arbatani S., Kövecses J., Kalantari M., Marchand N. Drill Bit Contact Dynamics Including Side Cutting: Simulation and Validation. Journal of Energy Resources Technology. 2017. № 139. P. 184-197. https://doi.org/10.1115/1.4035514

14. Shi J., Wang J., Liu X. The Nonlinear Dynamics Simulation of Drill String-drill Bit-rock Based on ABAQUS: 2nd International Conference on Civil, Materials and Environmental Sciences (April, 2015.). 2015. https://doi.org/10.2991/cmes-15.2015.125

15. Fourmeau M, Kane A, Hokka M. Experimental and numerical study of drill bit drop tests on Kuru granite. Phil. Trans. R. Soc. 2016. № 375. https://doi.org/10.1098/rsta.2016.0176

16. Hrydzhuk Y. S. Research of axial force and the torque action on a drill string at rotary and combined drilling methods. Scientific Bulletin of Ivano-Frankivsk National Technical University of Oil and Gas. 2018. № 2 (45). P. 7-15. https://doi.org/10.31471/1993-9965-2019-2(45)-7-15

17. Zhang W., Dang W., Chen W., Zhang Y. Individual Drilling Bit Design and Optimization in Mahu Area. MATEC Web of Conferences, 2017. 128. https://doi.org/10.1051/matecconf/201712805017

18. Залога В. А., Криворучко Д. В., Хвостик С. Н. Имитационная модель прямоугольного свободного резания. Вісник Сумського державного університету. 2005. № 11. С. 55-66.

19. Глембоцька Л., Балицька Н., Мельничук П., Мельник О. Комп’ютерне моделювання силового навантаження ножів торцевих фрез 3 циліндричною передньою поверхнею при різанні важкооброблюваних матеріалів. Вісник ТНТУ. 2019. № 1 (93). С. 70-80. https://doi.org/10.33108/ visnyk_tntu2019.01.070

20. Ковальчук Я., Шингера Н., Чорномаз Н. Напружено-деформівний стан нижнього пояса підкроквяної зварної ферми. Вісник ТНТУ. 2019. № 1 (93). С. 41-46. https://doi.org/10.33108/ visnyk_tntu2019.01.041

\title{
УДК 624.014
}

\section{СКІНЧЕНО-ЕЛЕМЕНТНЕ ДОСЛІДЖЕННЯ НАПРУЖЕНО-ДЕФОРМОВАНОГО СТАНУ ДОЛІТ ТИПУ РDС ПІД ЧАС ЇХНЬОЇ РОБОТИ}

\section{Тетяна Пригоровська; Олександр Пригоровський}

\author{
Івано-Франківський національний технічний університет нафти і газу, \\ Івано-Франківськ, Україна
}

\begin{abstract}
Резюме. Наведено результати скінчено-елементного моделювання напружено-деформованого стану доліт ріжучо-стираючої дії (PDC) під час їхньої експлуатації з метою визначення ділянок долота, де є найбільші напруження і деформації з метою вироблення подальших рекомендацій для удосконалення технології виготовлення долота. Визначення деформацій, які виникають під час експлуатації, має важливе значення, оскільки втрата долотом зовнішнього діаметру є однією із причин виходу з ладу долота. Виконане моделювання роботи долота із суцільним корпусом та із привареними лопатями. Під час скінчено-елементного дослідження засобами AnsysWorkBench (академічна ліцензія) встановлено, щцо як для суцільних, так і для доліт із привареними лопатями найбільші напруження спостерігаються 6 момент врізання долота у породу. Для всіх типів доліт ділянками із найбільшими напруженнями є нарізеві ділянки. Для доліт із привареними лопатями такими ділянками є і ділянки зварних швів. При цььому, деформачії, що виникають в області зварних швів, є причиною втратою долотом діаметра, щзо $\epsilon$ основним експлуатаційним показником роботи долота. Розглянуто залежність деформацій та напружень у циих ділянках від товщини зварного шва. Таким чином, зроблено висновок про те, щзо долота із привареними лопатями є більш схильними до втрати діаметра, тобто мають гірші показники експлуатації, що висуває певні вимоги до удосконалення технології виготовлення доліт такого типу. Запропоновано зменшення товщини зварного шва. Виконано скінчено-елементне дослідження експлуатації доліт із зварними швами у 5, 7 і 10 мм. Встановлено, щяо рівень напружень і деформацій, щуо виникають під час експлуатації, залежить від товщчини шва: зменшення товщчини зварного шва викликає зменшення напружень і деформацій.
\end{abstract}

Ключові слова: долота типу PDC, метод скінчених елементів, моделювання, напруженодеформований стан, нарізь, зварний шов. 